\title{
'We will have a lot to do when this is over'
}

\author{
By Pramod Subbaraman, BDJ reader panel, Hull, UK
}

$\mathrm{I}$ can't recall the last time that routine dentistry was suspended totally in this or any other country, not in my lifetime anyway. Ours is a profession guided by regulation and ethics and everything that has happened in the past few days has appeared very fluid and fast moving. The guidance has been missing at key moments and especially in England, has been late by many days at each step of the way. We don't know yet if irreversible damage has been caused by the delay. There are no guarantees and no one knows where this is headed or how long it will last.

Parking an entire profession on the bench is an extreme step, but it was a necessary step given the nature of our work and the nature of the threat that we face with the virus. As a diabetic and with a poor history of recovering from respiratory infections, I cannot risk an infection with COVID-19.

On a personal level, it has been painful to go into the practice only for a day or two each week to return calls and write prescriptions. As a clinical dentist facing patients in my routine as well as emergency out of hours sessions, I really miss my work. But I am very clear on one thing: you couldn't drag me to a practice or elsewhere in the NHS without appropriate Personal Protective Equipment (PPE). This is not a time to say 'yes sir, yes sir, three bags full sir' to authority and merely accept whatever comes our way. We need to ensure that we are properly protected in whatever we do and our personal safety must be our prime concern.

There is the worry about financial affairs too How long can this continue without adverse effects to my personal finances as well as the economy in general which will in turn affect my finances? My wife and toddler are stuck in India in that country's COVID-19 lockdown and I have no idea about when they can return to the UK and join me at home in Hull. It is such a shame that I'm having to suffer this period without them. All of this will take its toll on my emotional, physical and mental wellbeing, but I'm fortunate to have so many colleagues from the BDA and from the wider profession to chat with on Twitter and keep me sane. I welcome readers to tweet me @briteeth and keep the conversation going there.

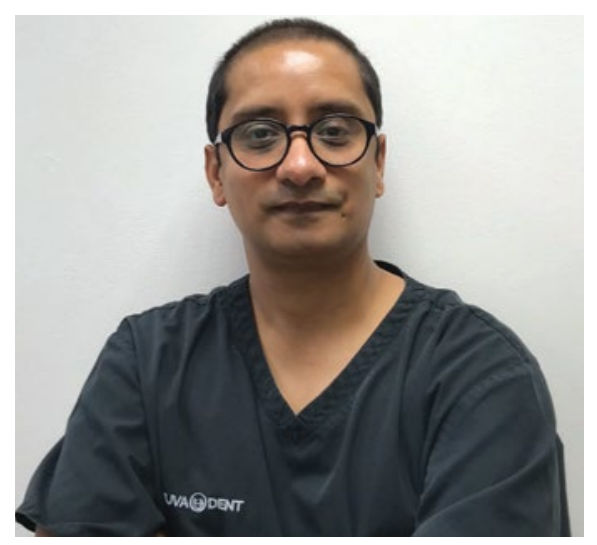

One good thing about the downtime is the fact that I can spend time reading and researching for my MA in Dental Law and Ethics. Focus groups and semi-structured interviews may have to be deferred indefinitely, but I can use this time in learning about qualitative research and possibly complete a literature review. After all, every cloud does have its silver lining.

Stay healthy, stay safe, and stay sane dental family. We will have a lot to do when this is over.

\section{GDC seeking dental professionals for FtP panel}

The General Dental Council (GDC) has begun a search for 24 dental professionals (18 dentists and six dental care professionals [DCPs]) to sit on its Fitness to Practise panel.

GDC Head of Adjudications, John Cullinane, said: 'There is no part of our lives that the current pandemic has not touched, and these are exceptionally worrying times for everybody. Several weeks into the "lockdown" we, like many organisations, are faced with tough decisions about what work can and should resume. While all but the most urgent fitness to practise hearings are currently suspended, we know that when restrictions are lifted, we're going to need to work through the hearings which have been delayed by all of this. That makes the search for new panellists, to replace those reaching the end of their term, all the more important and this is why we've decided to push ahead now?

The available positions, which pay $£ 353$ plus expenses per day, are for panellists to sit on the GDC's statutory committees which hear evidence and rule on dental professionals' fitness to practise, following investigations.

Those with an interest need to be available for 20-25 weekdays per year (for at least a week at a time) and be able to demonstrate their ability to analyse complex information and work with sensitive issues.

There are many benefits, beyond remuneration, for professionals sitting on the panel.

Helen Baker, a dentist who currently sits on the panel, said: 'I think it's increased my value to my practice, in that my continued exposure to the common pitfalls in dentistry has allowed me to highlight significant matters to my team. I also appreciate the skills and experience I have gained more generally, as they will stand me in good stead if I were to consider a career change, away from clinical dentistry. I'd have been very sorry to have missed the opportunity to be a panellist'.

All positions are for an initial four-year term, with a maximum length of service of eight years.

The application period opened on 7 April and closes on Sunday 3 May. Interviews are to be held in the fortnight 29 June to 10 July, with morning and afternoon slots available. For successful candidates, two-day induction sessions will be held on 6 and 7 October, or 20 and 21 October.

For more information about the roles and to apply, visit www.gdc-uk.org. 